\title{
Nove sonetos de Augusto dos Anjos
}

\author{
Reginaldo Bittencourt
}

Poeta particularíssimo não apenas dentro da literatura brasileira como também da universal - embora esta última dele não tome conhecimento - Augusto dos Anjos nasceu no Engenho Pau d'Arco, interior da Paraíba, em 1884, e faleceu em Leopoldina, estado de Minas Gerais, em 1914. Filho de fazendeiros, bacharelou-se em direito no Recife em 1907 e morreu pouco depois, de pneumonia, ocupando o cargo de diretor de um colégio público com a idade de 30 anos. Foi casado. Sua esposa pariu-lhe dois filhos: um, natimorto com sete meses de gestação, e outro que veio à luz sem maiores problemas. Ah: publicou um livro de poesias, "Eu", em 1912. Pronto: eis toda a história da vida de Augusto dos Anjos.

Mais ainda do que em Machado de Assis, é assombroso aqui o contraste entre uma existência inteiramente desprovida de lances românticos ou pitorescos, grandes tragédias ou sortes inesperadas, vivida à mais rigorosa risca da "normalidade", e a absoluta singularidade de uma obra artística extremamente pessoal, que deixa pasmos até aqueles que não a apreciam.

Mas não, Augusto não foi um Machado na qualidade de seu trabalho: sua poesia, feita fundamentalmente de sonetos, é cheia de altos e baixos, fato reconhecido pela crítica em geral e, antes de todos, pelo próprio poeta - em um soneto seu. Mas a honestidade - talvez seja esta a palavra -, a absoluta e despida - e 
eloquente - franqueza com que se expõe, enquanto artista e ser humano, ao transpor sua inspiração para os versos de seus poemas, talvez seja a explicação para o fato de, geração após geração, ter Augusto dos Anjos mantido sempre por estas nossas terras tropicais legiões de fãs ardorosos. Seu epíteto, mais que adequado: $O$ poeta da morte.

Indiscutivelmente, a grande dificuldade em verter-se Augusto para outra língua é a forma. Ele foi, acima de tudo, um sonetista: implacável quanto à observância das tradicionais regras de construção desse tipo de poema. Outro aspecto difícil é o bizarro e insofreável gosto do poeta pelo uso de léxicos estranhos à nossa língua em seu uso corrente, e mesmo no seu registro erudito: palavras que muitos dicionários nem mesmo registram (como "gasofiláceo" - neologismo?), e um gigantesco desfile de cientificismos, particularmente das ciências médicas e biológicas.

Quanto à forma: dois quartetos e dois tercetos, observar a quantidade de sílabas poéticas, os esquemas de rimas (e como gostava de rimar, esse rapaz!); quanto ao léxico: reproduzir seu hermetismo assim como seu oposto, pois Augusto combinava (sendo esta outra marca sua) o "elevado" com o "vulgar", saltando da profanação dos tálamos cristãos aos escarros nas bocas que se abrem, antes, à espera de um beijo. Isto e, é claro, a manutenção de seu conteúdo semântico, suas imagens, metáforas, sinéreses etc. Pronto: tal, pois, se me apresentava a tarefa a que me propus.

Desde o princípio soube que teria, por força de minhas limitações, que misturar, o menos desagradavelmente possível eu esperava, a observância desses rigores com passagens de maior liberdade. Em alguns momentos, fui feliz; noutros, nem tanto. Foi uma tarefa árdua, principalmente, acho, por se tratar, eu, de um neófito: é meu debut nesse tipo de trabalho. Mas creio que cheguei a um resultado, no geral, razoável.

Devo aqui, para finalizar, reconhecer o apoio inestimável do professor John Milton do departamento de Letras da FFLCH/USP, que, paciente, leu meu trabalho e ajudou-me em todos os pontos em 
que eu, ignorante, manipulei desastradamente seu tão belo e sonoro idioma materno.

\section{Lonesome}

Like a ghost to hide

In the loneliness of nature,

On solitary graves, I, one day,

Came, to stay, here at your side!

It was cold; but not this cold

Good to feel, in summer ways...

As a knife that sways, that slays,

As a knife, I say, this cold was!

But you didn't care for my Misery!

So I left, as if in need of nothing,

- Old coffin filled with stones -

Taking away the carcass,

A singular parchment of skin

With the gloomy rattling of bones! 
Reginaldo Bittencourt. Nove sonetos de Augusto dos Anjos

\section{Solitário}

Como um fantasma que se refugia

Na solidão da natureza morta,

Por trás dos ermos túmulos, um dia,

Eu fui refugiar-me à tua porta!

Fazia frio e o frio que fazia

Não era esse que a carne nos conforta...

Cortava assim como em carniçaria

$\mathrm{O}$ aço das facas incisivas corta!

Mas tu não vieste ver minha Desgraça!

E eu saí, como quem tudo repele,

- Velho caixão a carregar destroços -

Levando apenas na tumbal carcaça

O pergaminho singular da pele

E o chocalho fatídico dos ossos! 


\section{Obsession of blood}

Awoke; there, blood... - Horrible!

Forehead in flames... He was to die, he said.

Rushed to the mirror. So young, Ah!

Nonsense. It can't be that bad!

Rode up. And then he saw, on the butchers' chopper,

Leaving a crimson stream behind,

The dead meat he was to find

On his table, to appease his hunger!

In the hell of such a vision, he saw

Mountains of blood covering the floor,

Guts lying on his bed...

And he loved, yelling in barbarism,

The monstrous monochromatism

Of universal red! 
Reginaldo Bittencourt. Nove sonetos de Augusto dos Anjos

\section{A obsessão de sangue}

Acordou, vendo sangue... - Horrível! O osso

Frontal em fogo... Ia talvez morrer,

Disse. Olhou-se no espelho. Era tão moço,

Ah! certamente não podia ser!

Levantou-se. E eis que viu, antes do almoço,

Na mão dos açougueiros, a escorrer

Fita rubra de sangue muito grosso,

A carne que ele havia de comer!

No inferno da visão alucinada,

Viu montanhas de sangue enchendo a estrada,

Viu vísceras vermelhas pelo chão...

E amou, com um berro bárbaro de gozo,

o monocromatismo monstruoso

Daquela universal vermelhidão! 


\section{Loser's psychology}

I, child of ammonia and carbon,

Monster of darkness and brightness,

Suffer, from the dawn of mind,

Evil influences of zodiac signs.

Hypochondria settles deeply in me,

And this place makes me feel sick...

In my mouth is the same anguish of a man

Whose heart, by disease, is thick.

And the worm - such a worker of ruins -

Rotten blood rivers he eats

And, to whole Life, war declare does he,

Spies my eyes he longs to gnaw.

Only my hair shall remain, and that's all,

In the inorganic cold of the earth! 
Reginaldo Bittencourt. Nove sonetos de Augusto dos Anjos

\section{Psicologia de um vencido}

Eu, filho do carbono e do amoníaco,

Monstro de escuridão e rutilância,

Sofro, desde a epigênesis da infância,

A influência má dos signos do zodíaco.

Profundissimamente hipocondríaco,

Este ambiente me causa repugnância...

Sobe-me à boca uma ânsia análoga à ânsia

Que se escapa da boca de um cardíaco.

Já o verme - este operário das ruínas -

Que o sangue podre das carnificinas

Come, e à vida em geral declara guerra,

Anda a espreitar meus olhos para roê-los,

E há-de deixar-me apenas os cabelos,

Na frialdade inorgânica da terra! 


\section{Intimate verses}

See?! No one came to the astounding

Funeral of your last dream.

Only Ingratitude - this beast -

Was your everlasting mate!

Get used to the mud that awaits!

Man, living in this miserable land,

Amongst animals, longs to be

A wild animal, as well.

Take a match. Light your cigarette!

The sweetest kiss precedes the spit,

The gentle hand hides the stone to be thrown.

So, if anybody weeps for your wounds and claims his sorrow,

Spit in this kissing mouth, then,

Stone to death this vile gentle hand! 
Reginaldo Bittencourt. Nove sonetos de Augusto dos Anjos

\section{Versos íntimos}

Vês?! Ninguém assistiu ao formidável

Enterro de tua última quimera.

Somente a Ingratidão - esta pantera -

Foi tua companheira inseparável!

Acostuma-te à lama que te espera!

O Homem, que, nesta terra miserável,

Mora, entre feras, sente inevitável

Necessidade de também ser fera.

Toma um fósforo. Acende teu cigarro!

O beijo, amigo, é a véspera do escarro,

A mão que afaga é a mesma que apedreja.

Se a alguém causa inda pena a tua chaga,

Apedreja essa mão vil que te afaga,

Escarra nessa boca que te beija! 


\section{Modern buddhism}

Take, doc, these scissors, and... cut My - Oh! - so particular self.

What does it matter to me the beasts to eat

All of my flesh, since I'll be dead?!

Alas! A vulture landed on my fate!

For the lilies I see in the lake,

Before my eyes they turn to fake

Against the rude back of a hand!

Fade away, life o' mine, farewell,

Just as a single fallen cell

In the aberration of an ovule that won't grow;

But the memories I miss so far,

Forever convulse behind the bars

Of the final line I'll make in this world! 
Reginaldo Bittencourt. Nove sonetos de Augusto dos Anjos

\section{Budismo moderno}

Tome, Dr., esta tesoura, e... corte

Minha singularíssima pessoa.

Que importa a mim que a bicharia roa

Todo o meu coração, depois da morte?!

Ah! Um urubu pousou na minha sorte!

Também, das diatomáceas da lagoa,

A criptógama cápsula se esbroa

Ao contato de bronca destra forte!

Dissolva-se, portanto, minha vida

Igualmente a uma célula caída

$\mathrm{Na}$ aberração de um óvulo infecundo;

Mas o agregado abstrato das saudades

Fique batendo nas perpétuas grades

Do último verso que eu fizer no mundo! 


\section{Ricordanza della mia gioventú}

My wet nurse, Guilhermina, used to steal

The coins her Master gave to me.

Mistress, my mother, scolded her...

She saw on that my own ruin!

My wet nurse, hypocrite, cried out

Just as if she was only a child:

"I didn't do a thing!" she said,

It was someone else, it was someone bad.

Notwithstanding, now I can see

That the real thieving was done by me...

Because you, while deceiving my father,

Stole only gold, but I, my wet nurse,

Stole the one whom you gave birth,

I stole the breast from your little daughter! 
Reginaldo Bittencourt. Nove sonetos de Augusto dos Anjos

\section{Ricordanza della mia gioventú}

A minha ama-de-leite Guilhermina

Furtava as moedas que o Doutor me dava.

Sinhá-Mocinha, minha mãe, ralhava...

Via naquilo a minha própria ruína!

Minha ama, então, hipócrita, afetava

Suscetibilidades de menina:

“Não, não fora ela!" - e maldizia a sina,

Que ela absolutamente não furtava.

Vejo entretanto, agora, em minha cama,

Que a mim somente cabe o furto feito...

Tu só furtaste a moeda, o ouro que brilha.

Furtaste a moeda só, mas eu, minha ama,

Eu furtei mais, porque furtei o peito

Que dava leite para tua filha! 


\section{Worm god}

Universal factor of transformism,

Born in a teleological nest,

In the worst, as in the best,

Worm - his lurid name of baptism.

Never to use the filthy exorcism

In his duty of every days,

Alongside with bacteria he lies,

Free from the veils of anthropomorphism.

Rotten limbs for breakfast

- Guts for lunch, eyes for dinner,

Swollen hands - and all o' the rest...

His are the possessions of the decayed content.

And if you take a look on Life's testament,

To his children is left the best! 
Reginaldo Bittencourt. Nove sonetos de Augusto dos Anjos

\section{O deus-verme}

Fator universal do transformismo.

Filho da teleológica matéria,

Na superabundância ou na miséria,

Verme - é o seu nome obscuro de batismo.

Jamais emprega o acérrimo exorcismo

Em sua diária ocupação funérea,

E vive em contubérnio com a bactéria,

Livre das roupas do antropomorfismo.

Almoça a podridão das drupas agras,

Janta hidrópicos, rói vísceras magras

E dos defuntos novos incha a mão...

Ah! Para ele é que a carne podre fica,

E no inventário da matéria rica

Cabe aos seus filhos a maior porção! 


\section{The eternal grief}

The man on whom has fallen

The sad plague of the world, the sad man,

For all the centuries he's condemned

To a woe that has no end!

He believes nothing, for nothing can cease

This grief he watches alone.

Tries to resist, but it's gone,

From this wound he shan't be released!

He knows his pain, but what he knows not

Is that this grief which makes his lot

Is greater than his life, is that this grief

Goes on when his body is no more,

And after the man had turned to a worm,

This grief escorts him still! 
Reginaldo Bittencourt. Nove sonetos de Augusto dos Anjos

\section{Eterna mágoa}

O homem por sobre quem caiu a praga

Da tristeza do mundo, o homem que é triste

Para todos os séculos existe

E nunca mais o seu pesar se apaga!

Não crê em nada, pois, nada há que traga

Consolo à Mágoa, a que só ele assiste.

Quer resistir, e quanto mais resiste

Mais se lhe aumenta e se lhe afunda a chaga!

Sabe que sofre, mas o que não sabe

É que essa mágoa infinda assim, não cabe

Na sua vida, é que essa mágoa infinda

Transpõe a vida do seu corpo inerme;

E quando esse homem se transforma em verme

É essa mágoa que o acompanha ainda! 


\section{An anthem to pain}

Pain, health of the fading beings.

Wealth of the soul, treasure of the brain,

Happiness of those called tear glands,

Whence come the weeping...

You are supreme! My atoms exult with grace

In belonging to you, Pain! Home

Of the wretches, sun of the mind, gold

Adorning misfortunes everywhere!

I'm your lover! I burn inside you so much...

With the magic corpuscles of touch,

I hold the orchestra of flames you play...

And then, with no convulsion to harass,

My infinite joy is to possess

All the brightness of your ways! 
Reginaldo Bittencourt. Nove sonetos de Augusto dos Anjos

\section{Hino à dor}

Dor, saúde dos seres que se fanam.

Riqueza de alma, psíquico tesouro,

Alegria das glândulas do choro

De onde todas as lágrimas emanam...

És suprema! Os meus átomos se ufanam

De pertencer-te, oh! Dor, ancoradouro

Dos desgraçados, sol do cérebro, ouro

De que as próprias desgraças se engalanam!

Sou teu amante! Ardo em teu corpo abstrato.

Com os corpúsculos mágicos do tato

Prendo a orquestra de chamas que executas...

E, assim, sem convulsão que me alvoroce,

Minha maior ventura é estar de posse

De tuas claridades absolutas! 